\title{
Scientists split over regulations on sonar use
}

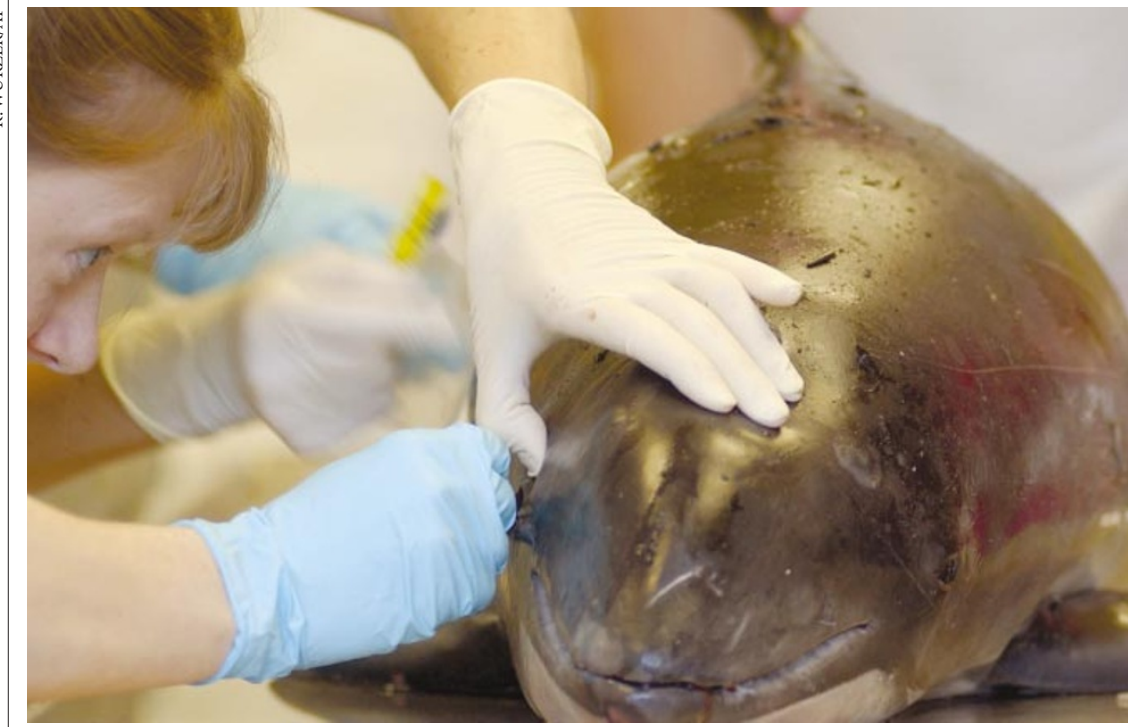

Dead in the water: are navy sonar operations to blame for porpoise deaths off Washington state?

\section{Rex Dalton, San Diego}

The US Congress is considering proposals that will make it easier to get permission to use high-volume sonars in the ocean - just as fresh evidence suggests that their noise can harm marine mammals.

Capitol Hill is looking at two measures to loosen the 1972 Marine Mammal Protection Act (MMPA), which sets guidelines for noisy experiments in the oceans. One would simplify the rules, making it easier to get permission to do the experiments. The second would exempt the US Navy from the regulations on the grounds of national security.

The changes are supported by the navy and by some geophysicists, who want to use noise-generating devices to study geological formations on the ocean floor. But they are strongly opposed by many marine biologists. "There is a huge split over the issue," says
John Hildebrand, who studies marine mammal acoustics at the Scripps Institution of Oceanography in La Jolla, California.

In a Brief Communication in this issue of Nature, a team led by Paul Jepson of the Institute of Zoology in London concludes that 14 whale deaths off the Canary Islands last year may have been caused by decompression sickness after the animals shot to the surface to escape sonars during Spanish-led international naval exercises (page 575). The team says the sonar appears to have caused gas bubbles to form in the blood, damaging the whales' livers and kidneys.

Experts say that the study provides some of the most direct evidence to date that sonars can kill marine mammals. "This report has the potential to be the 'smoking gun' on the cause of sonar-related mammal strandings," says Hildebrand. "It certainly focuses on the potential dangers of sonar, which need to be thoroughly investigated."

On 25 September, however, the oceans subcommittee of the House of Representatives Committee on Resources passed a 'reauthorization' of the MMPA that would give government agencies more freedom to permit experiments in the oceans. Agencies could also ask for stronger proof that a study might cause damage. The bill will soon be considered by the full committee, where some Democrats will seek to tighten its provisions.

Meanwhile, a House-Senate conference committee is due to consider a 2004 military spending authorization bill that would exempt the navy from the sonar rules. "We fear something bad" is going to come out of the conference, says Karen Wayland, a geologist with the National Resources Defense Council, an environmental group that took successful court action to block the navy's use of some sonar devices (see Nature 425, 6; 2003).

John Orcutt, a geophysicist and deputy director of Scripps, says that he favours the proposed modifications to the MMPA, so that researchers can secure permits more easily than at present. "The process is tremendously flawed," he says. Orcutt is worried, however, that the navy exemption would encourage the military to do all of its own experiments and stop supporting external researchers, who would remain constrained by the law.

But marine biologist Ken Balcomb, director of the Center for Whale Research in Friday Harbor, Washington, says recent deaths and strandings of marine mammals should persuade physical oceanographers and Congress - to worry more about protecting these animals instead of loosening research regulations.

\section{European Commission dips toe into military research}

\section{Marika Willerroider, Munich}

Plans for a European defence research agency took a tentative step forward this week, when the European Commission (EC) announced that it would fund $\mathrm{E} \mathbf{6 5}$ million (US\$76 million) of security-related research and development over three years.

The EC will spend the money on research into what it terms "non-offensive" military capabilities, such as non-lethal weapons for riot control or early-warning systems against bioterrorism. $\mathrm{E} 9$ million will be released to kick-start research in 2004. The rest will need approval by the European parliament.

The pilot programme - the EC's first foray into military research — will fund joint academic-industry projects, and a call for proposals will go out in January, an EC spokesman said. The European Security Research Programme will be jointly administered by the EC directorates for research and enterprise.

But the project could form the nucleus of a much wider involvement in military research. On 6 October, a group of advocates including Lord Robertson, the NATO secretary general, presented a plan for a fully-fledged European Union (EU) defence research agency to EC officials. The meeting also included the chief executives of electronics companies Siemens and Ericsson, and the European Aeronautic Defence and Space Company. Europe's military-equipment industry has been lobbying for years for such an outfit, possibly along similar lines to the US Defense Advanced Research Projects Agency (see Nature 421, 465; 2003).

Advocates would like to see it up and running by 2007 , but this is unlikely as the new agency will require approval from the European parliament, says Elly Plooij-van Gorsel, a Dutch member of the parliament. She adds that military research needs funds beyond the existing EU research budget. 